\title{
Clinically Relevant Chemotherapeutics Have the Ability to Induce Immunogenic Cell Death in Non-Small Cell Lung Cancer
}

\author{
Tal Flieswasser ${ }^{1,2, *}$, Jinthe Van Loenhout ${ }^{1} \mathbb{B}$, Laurie Freire Boullosa ${ }^{1}$, Astrid Van den Eynde ${ }^{1}$, \\ Jorrit De Waele ${ }^{1}{ }^{10}$, Jonas Van Audenaerde ${ }^{1}{ }^{1}$, Filip Lardon ${ }^{1}$, Evelien Smits ${ }^{1,3}{ }^{\circledR}$, \\ Patrick Pauwels ${ }^{1,2}$ and Julie Jacobs ${ }^{1,2}$ (D) \\ 1 Center for Oncological Research (CORE), Integrated Personalized and Precision Oncology \\ Network (IPPON), 2610 Wilrijk, Belgium; jinthe.vanloenhout@uantwerpen.be (J.V.L.); \\ laurie.freireboullosa@uantwerpen.be (L.F.B.); astrid.vandeneynde@uantwerpen.be (A.V.d.E.); \\ jorrit.dewaele@uantwerpen.be (J.D.W.); jonas.vanaudenaerde@uantwerpen.be (J.V.A.); \\ filip.lardon@uantwerpen.be (F.L.); evelien.smits@uza.be (E.S.); patrick.pauwels@uza.be (P.P.); \\ julie.jacobs@uantwerpen.be (J.J.) \\ 2 Department of Pathology, Antwerp University Hospital, 2650 Edegem, Belgium \\ 3 Center for Cell Therapy and Regenerative Medicine, Antwerp University Hospital, 2650 Edegem, Belgium \\ * Correspondence: tal.flieswasser@uantwerpen.be
}

Received: 2 June 2020; Accepted: 12 June 2020; Published: 16 June 2020

\begin{abstract}
The concept of immunogenic cell death (ICD) has emerged as a cornerstone of therapy-induced anti-tumor immunity. To this end, the following chemotherapies were evaluated for their ability to induce ICD in non-small cell lung cancer (NSCLC) cell lines: docetaxel, carboplatin, cisplatin, oxaliplatin and mafosfamide. The ICD hallmarks ATP, ecto-calreticulin, HMGB1, phagocytosis and maturation status of dendritic cells (DCs) were assessed in vitro. Furthermore, an in vivo vaccination assay on C57BL/6J mice was performed to validate our in vitro results. Docetaxel and the combination of docetaxel with carboplatin or cisplatin demonstrated the highest levels of ATP, ecto-calreticulin and HMGB1 in three out of four NSCLC cell lines. In addition, these regimens resulted in phagocytosis of treated NSCLC cells and maturation of DCs. Along similar lines, all mice vaccinated with NSCLC cells treated with docetaxel and cisplatin remained tumor-free after challenge. However, this was not the case for docetaxel, despite its induction of the ICD-related molecules in vitro, as it failed to reject tumor growth at the challenge site in $60 \%$ of the mice. Moreover, our in vitro and in vivo data show the inability of oxaliplatin to induce ICD in NSCLC cells. Overall with this study we demonstrate that clinically relevant chemotherapeutic regimens in NSCLC patients have the ability to induce ICD.
\end{abstract}

Keywords: non-small cell lung cancer; chemotherapy; immunogenic cell death

\section{Introduction}

Non-small cell lung cancer (NSCLC) represents an estimated 85\% of all lung cancers, accounting for 2.1 million new lung cancer cases and approximately 1.8 million deaths per year worldwide [1]. It remains the leading cause of cancer mortality worldwide with a 5-year overall survival rate of only $15 \%$ for all stages, according to the World Health Organization [2,3]. The first-line treatment of advanced NSCLC in the majority of patients still consists of conventional chemotherapy (regimens with platinum-based agents) to achieve tumor response or stable disease [4].

In the last decade, important therapeutic advances took place in the treatment of NSCLC, such as development of small molecular tyrosine kinase inhibitors (TKIs) targeting specific genetic alterations 
as well as immunotherapy, which has paved its way into the clinic as first- and second-line treatment [5]. Especially the emergence of immune checkpoint inhibitors, more specifically anti-programmed cell death protein 1 (PD-(L)1), represents a landmark of success in a broad range of tumor types with a great number of ongoing clinical trials and recent Food and Drug Administration (FDA) and European Medicines Agency (EMA) approvals to treat different tumor types, including NSCLC [6-11]. Although recent targeted and immunotherapeutic strategies have shown remarkable clinical responses as single agents, such durable responses are only observed in a minority of patients and in addition, resistance nearly always develops [12,13]. Thus going beyond monotherapy to combination regimens which increase immunostimulatory effects is a worthwhile strategy to circumvent this challenge [14].

While in the past, conventional cancer chemotherapeutic agents were used with the main aim of achieving tumor cell toxicity, recent studies have demonstrated that certain chemotherapeutic drugs can modulate the anti-tumor immune response $[15,16]$. Different conventional chemotherapeutic agents can activate innate and adaptive anti-tumor responses, and thus increase treatment efficacy [17]. The immunomodulatory properties of chemotherapeutic agents, commonly used for NSCLC in the clinic, have already been described in literature to some extent. For instance, cisplatin (CDDP) has been shown to reduce the number of myeloid-derived suppressor cells in a murine B16 melanoma model [18], while another study reported that CDDP can sensitize tumor cells to Fas-mediated tumor cell killing by enhancing Fas expression on tumor cells, thereby increasing their vulnerability to immune cells expressing Fas ligand [19]. In addition, CDDP has been shown to upregulate expression of MHC class I chain related molecule A and B, leading to enhanced NK cell-mediated killing of NSCLC cells [20,21]. Moreover, CDDP and its analog, carboplatin (CARBO), can induce activation of macrophages and increase their antitumor activity against murine sarcoma cells [22]. Furthermore, docetaxel (DOC) treatment of peripheral blood samples of NSCLC patients resulted in a reduced amount of regulatory $\mathrm{T}$ cells in vitro [23].

In addition to these immunomodulatory properties of chemotherapeutic agents, another way to efficiently activate a long-term anti-tumor immune response is through the induction of immunogenic cell death (ICD) [24]. Therapy-treated tumor cells succumbing to ICD release certain damage-associated molecular patterns (DAMPs), such as early lysosomal adenosine triphosphate (ATP) secretion (find-me signal), pre-apoptotic translocation of the endoplasmic reticulum (ER) chaperone protein calreticulin (ecto-CALR) to the tumor cell surface (eat-me signal) and post-mortem release of the nuclear protein high mobility group box 1 (HMGB1) $[16,25,26]$. Upon release of DAMPs, dendritic cells (DCs) are recruited to the tumor site. There, they process tumor antigens and undergo subsequent maturation and activation, leading to activation of an adaptive anti-tumor immune response [27]. The 'gold standard' to confirm the ability of a therapeutic agent to ICD, currently relies on the in vivo vaccination assay [28]. In this setting, immune competent mice are subcutaneously (s.c.) injected with the vaccine (treated tumor cells) on one side of the flank, while the challenge (live cells) is injected in the opposite side of the flank. The percentage of tumor-free mice represents the degree of immunogenicity of the tested compound [28]. To date, chemotherapies that are mostly used as positive controls for ICD include oxaliplatin (OXA), cyclophosphamide (CP), mitoxantrone, epirubicin and doxorubicin to compare the immunogenicity of a therapeutic agent in certain cancer models [28-33].

Currently, extensive data on the ICD potential of clinically relevant chemotherapeutics for NSCLC is lacking. To this end our data provide novel insights into the in vitro and in vivo potential of various first- and second-line chemotherapeutic agents for NSCLC using a panel of human and murine NSCLC cell lines.

\section{Materials and Methods}

\subsection{Cell Lines and Cell Culture}

Cell lines A549, NCI-H1975 and NCI-H1650 were purchased from the American Type Culture Collection (ATCC, Molsheim Cedex, France). In addition, the Lewis Lung carcinoma (3LL) cell 
line (gift from Dr. Carsten Riether, Department of Clinical Research, University of Bern; derived from the lung of a C57BL/6J mouse) was included. A549 and 3LL were cultured in Dulbecco's Modified Eagle Medium (DMEM, Life Technologies, 10938-025, Merelbeke, Belgium) supplemented with 10\% FBS (Life Technologies, 10270-106), 1\% penicillin $(100 \mathrm{U} / \mathrm{mL}) /$ streptomycin $(100 \mu \mathrm{g} / \mathrm{mL}$; Life Technologies, 15140-122) and 2 mM L-glutamine (L-Glut, Life Technologies, 25030-024). NCI-H1975 and NCI-H1650 were cultured in Roswell Park Memorial Institute Medium (RPMI, Life Technologies, 52400-025) supplemented as described above. Cells were grown as monolayers and were maintained in exponential growth in $5 \% \mathrm{CO}_{2}+95 \%$ air in a humidified incubator at $37^{\circ} \mathrm{C}$. All cell cultures were confirmed as Mycoplasma free using the Mycoalert ${ }^{\circledR}$ Mycoplasma detection kit (Lonza, LT07-218, Verviers, Belgium).

\subsection{Cytotoxicity of Different Chemotherapies}

The following chemotherapeutic agents were used: DOC (S1148), CARBO (S1215), CDDP (S1166), OXA (S1224) and pemetrexed (PEM, S1135; all purchased from Selleckchem, Munich, Germany) and mafosfamide (MF, the active metabolite of cyclophosphamide; purchased from Niomech-IIT $\mathrm{GmbH}, \mathrm{D}-17272)$. To evaluate cytotoxicity of the different chemotherapeutic agents, NSCLC cells were seeded in 96-well plates, incubated overnight and treated for $72 \mathrm{~h}$ with either CDDP $(0-20 \mu \mathrm{M})$, DOC $(0-50 \mu \mathrm{M})$, OXA $(0-50 \mu \mathrm{M})$, MF $(0-300 \mu \mathrm{M})$, CARBO $(0-50 \mu \mathrm{M})$ or PEM $(0-10 \mu \mathrm{M})$ as single agents. After treatment, cell monolayers were fixed with $10 \%$ trichloroacetic acid for $1 \mathrm{~h}$ at $4{ }^{\circ} \mathrm{C}$ and stained with $100 \mu \mathrm{L} 0.1 \%$ sulforhodamine B, as previously described [34]. The inhibitory concentration (IC) of the drug that leads to $40 \%\left(\mathrm{IC}_{40}\right)$ and $50 \%$ ( $\mathrm{IC}_{50}$ ) growth inhibition, was calculated using the WinNonlin software (Pharsight). All experiments were performed at least in triplicate. Combination regimens consisted of the $\mathrm{IC}_{50}-72 \mathrm{~h}$ value of DOC with the $\mathrm{IC}_{40}$ value of either CARBO or CDDP.

\subsection{ATP Release}

Extracellular ATP was measured in the conditioned media (supplemented with heat inactivated FBS) $24 \mathrm{~h}$ after chemotherapeutic treatment using the ENLITEN ${ }^{\circledR}$ ATP assay system, according to the manufacturer's protocol (Promega, FF2000, Leiden, The Netherlands). The bioluminescent signal was measured using a VICTOR ${ }^{\mathrm{TM}}$ plate reader (PerkinElmer).

\subsection{Ecto-CALR Expression}

Forty-eight hours after treatment, cells were harvested and incubated with $5 \%$ normal goat serum (NGS, Sigma-Aldrich, G9023), followed by washing and incubation with Alexa Fluor 488-conjugated anti-CALR (Abcam, ab196158, 1/100 dilution) antibody for $40 \mathrm{~min}$. Prior to sample analysis, cells were stained with Annexin V (AnnV, APC-conjugated; BD, 550474) and propidium iodide (PI; BD Biosciences, 556463) to gate on non-permeabilized cells $\left(\mathrm{AnnV}^{+/-}, \mathrm{PI}^{-}\right)$for ecto-CALR expression, as previously described [35]. Isotype control (rabbit IgG, Abcam, 199091, 1/100 dilution, Cambridge, UK) was included to correct for non-specific binding. Flow cytometric acquisition was performed on a BD Accuri $^{\mathrm{TM}}$ C6 instrument (BD Biosciences). Data analysis was performed using FlowJo v10.1 software (TreeStar).

\subsection{HMGB1 Release}

Release of HMGB1 was analyzed $72 \mathrm{~h}$ after treatment in the conditioned media using an enzyme-linked immunosorbent assay (IBL, ST51011) according to the instructions of the manufacturer. The absorption was measured via the iMARK ${ }^{\mathrm{TM}}$ plate reader (Bio-rad).

\subsection{In Vitro Generation of Human Monocyte-Derived DCs}

Buffy coats from healthy donors (Red Cross Flanders Blood Service, Belgium) were collected and human peripheral blood mononuclear cells (PBMCs) were isolated by LymphoPrep gradient separation 
(Sanbio, 1114547). Monocytes were isolated from PBMCs using CD14 microbeads according to the manufacturer's protocol (Miltenyi Biotec, 272-01, Utrecht, The Netherlands) with purity $>90 \%$ after isolation. Subsequently, cluster of differentiation (CD) 14 positive $\left(^{+}\right)$cells were plated at a density of 1.25-1.35 × $10^{6}$ cells/mL in 1640 RPMI (Life Technologies, 52400-025) supplemented with $2.5 \%$ human $\mathrm{AB}$ (hAB, Sanbio, A25761) serum, $800 \mathrm{U} / \mathrm{mL}$ granulocyte-macrophage colony stimulating factor (GM-CSF; Gentaur, 04-RHUGM-CSF) and $20 \mathrm{ng} / \mathrm{mL}$ interleukin (IL)-4 (Miltenyi Biotec, 130-094-117) at day 0 , as previously described [36].

\subsection{Phagocytosis and Maturation Status of DCs}

After in vitro generation of DCs, NCI-H1975, A549 and NCI-H1650 cells were labelled with PKH67, a green fluorescent membrane dye (Sigma Aldrich, MIDI67), prior to plating them out on day 3. NSCLC cells were treated with chemotherapy on day 4. On day 5, immature DCs were stained with cytoplasmic violet-fluorescent CellTracker Violet BMQC dye (Invitrogen, C10094) and effector (E) and target (T) cells were placed in coculture at a 1:1 (E:T) ratio. Supernatant (SN) was stored $\left(-20^{\circ} \mathrm{C}\right)$, cells were collected and immediately used for flowcytometric detection of DC maturation markers and phagocytosis on day 7. Cells were stained with CD80-PerCP5.5 (Biolegend, 400150) and CD86-PE-Cy7 (BD Biosciences, 557872) to assess DC maturation (Violet ${ }^{+}$population). Isotype controls (PerCP5.5, Biolegend, 305232; PE-Cy7, BD Biosciences, 557872) were included to subtract aspecific signals from measured fluorescence intensity. Phagocytosis of NSCLC cells was assessed by gating on the PKH6 $7^{+}$Violet $^{+}$population, as previously described [35]. Acquisition was performed on a FACSAria II (BD Biosciences). Data analysis was performed using FlowJo v10.1 software (TreeStar).

\subsection{In Vivo Vaccination Assay}

Six-week old immunocompetent female C57BL/6J mice were purchased from Charles River Laboratories and housed at the Animal Center (University of Antwerp) in randomized cages (five per cage) with a $12 \mathrm{~h}$ day/night cycle and with food and water ad libitum.

\subsubsection{In Vitro Preparation of Treated NSCLC Cell Vaccine}

On day 0 , 3LL cells $\left(1 \times 10^{6}\right.$ cells $\left./ \mathrm{mL}\right)$ were plated out in a T175 flask $\left(5 \times 10^{6}\right.$ cells in total $)$ and resuspended in supplemented DMEM. On day 1, 3LL cells were treated with either vehicle (phosphate-buffered saline; PBS) or chemotherapy $\left(\mathrm{IC}_{50}-72 \mathrm{~h}\right.$ for monotherapies and additional $\mathrm{IC}_{40}-72 \mathrm{~h}$ of either CARBO or CDDP in the combination regimen with DOC). On day 2, floating cells were collected, washed with PBS and adjusted to the appropriate concentration $\left(1 \times 10^{6}\right.$ cells $\left./ 100 \mu \mathrm{L}\right)$. Washed 3LL cells were resuspended in PBS $\left(10 \times 10^{6} / \mathrm{mL}\right)$ and incubated $\left(37^{\circ} \mathrm{C}\right)$ for $48 \mathrm{~h}$ to decrease viability (viability varied around $26-61 \%$ at day 3 ) and guarantee no tumor growth at the vaccination site. On day 5 , the vaccine of treated 3LL cells (viability below $10 \%$ ) was subcutaneously (s.c.) injected at the lower-right side of the abdomen $(100 \mu \mathrm{L} /$ mouse). The following week, mice were vaccinated again according to the protocol, as described above.

\subsubsection{In Vitro Preparation of Live NSCLC Cells for Challenge}

Live 3LL cells were collected and counted (with trypan blue) to adjust the concentration of living NSCLC cell suspension to 50,000 cells/100 $\mu \mathrm{L}$ of PBS per mouse. Live cells were initially injected seven days after 2nd vaccination at the challenge site on the left side of the abdomen. After a follow-up period of two weeks, all mice were re-challenged with live 3LL cells.

\subsubsection{In Vivo Follow-Up of Mice}

Tumor size was measured three times a week using a caliper and weight was measured to detect potential toxicities. Mice were euthanized when reaching their ethical endpoint (volume $>1500 \mathrm{~mm}^{3}$ 
or deep ulceration). All animal experiments were approved by the Antwerp Ethics Committee for Animal Testing (ECD-2018-53).

\section{Statistical Analysis}

Prism 8.02 software (GraphPad) was used for data comparison and graphical data representations. SPSS Statistics 25 software (IBM) was used for statistical computations. The Kruskal-Wallis test was used to compare means between more than two groups. The Mann-Whitney U test was used to compare means between two groups. All statistical tests were performed on a minimum of three independent experiments. The Log-rank test was used to compare survival probability between different groups. $p$-value $\leq 0.05$ was considered statistically significant.

\section{Results}

\subsection{Cytotoxicity of Different Chemotherapeutic Agents towards NSCLC Cell Lines}

Dose response curves of chemotherapeutic agents towards NSCLC cell lines were assessed in a panel of five NSCLC cell lines (Figure 1). Of note, PEM, a chemotherapeutic agent which is commonly used in NSCLC, was initially included in the experiments. However, no dose-response curve with cell viability of $<50 \%$ could be obtained for all cell lines using PEM (0-10 $\mu \mathrm{M}$; Figure S1).
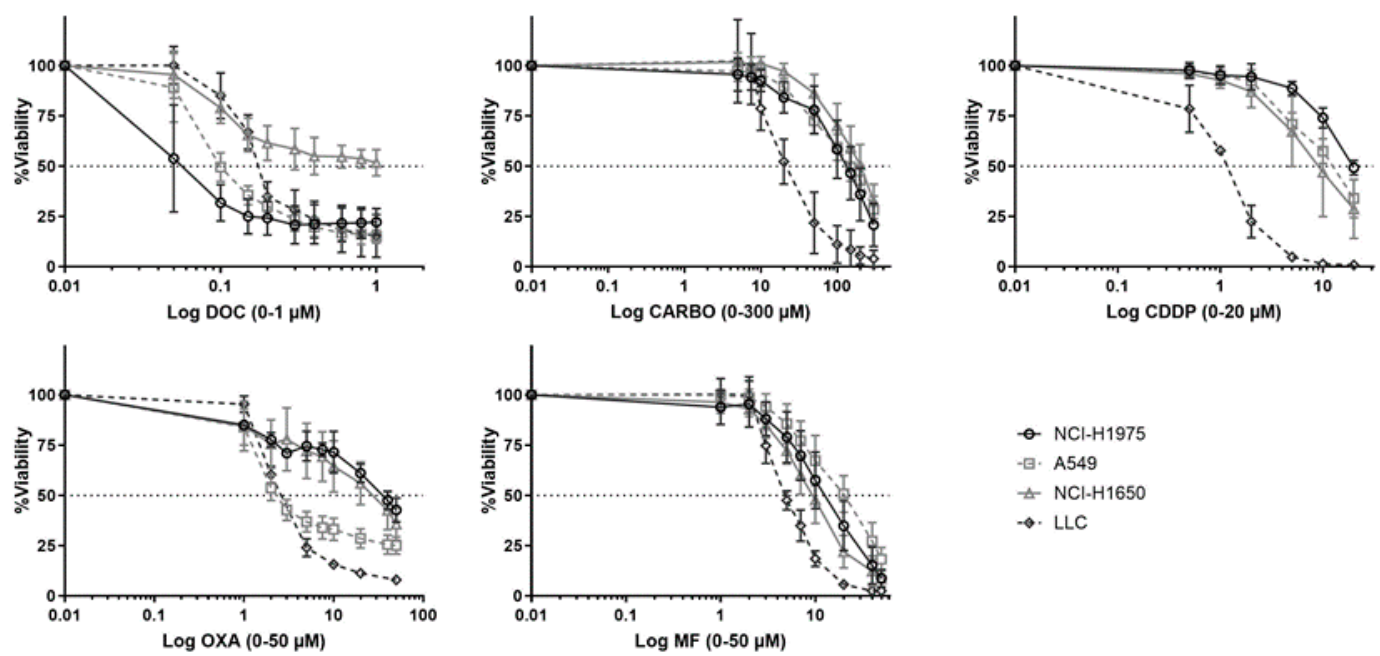

Figure 1. Dose-response curves of different chemotherapeutics in NSCLC cell lines. Survival curve after $72 \mathrm{~h}$ of treatment with docetaxel (DOC, 0-1 $\mu \mathrm{M}$ ), carboplatin (CARBO, 0-300 $\mu \mathrm{M}$ ), cisplatin (CDDP, 0-20 $\mu \mathrm{M}$ ), oxaliplatin (OXA, 0-200 $\mu \mathrm{M}$ ) and mafosfamide (MF, 0-80 $\mu \mathrm{M}$ ) in the NCI-H1975, A549, NCI-H1650 and 3LL cell line. Experiments were performed at least in triplicate. Error bars represent the standard deviation.

While NCI-H1975 was most sensitive to DOC $(0.029 \mu \mathrm{M} \pm 0.48)$, this cell line was most resistant to CDDP $(20 \mu \mathrm{M} \pm 1.6)$ and OXA $(42 \mu \mathrm{M} \pm 0.51)$ compared to other cell lines. NCI-H1650 cells were most resistant to CARBO $(189.30 \mu \mathrm{M} \pm 1.38)$. The murine $3 \mathrm{LL}$ was most sensitive to CARBO $(17 \mu \mathrm{M} \pm 2.20), \mathrm{CDDP}(1.92 \mu \mathrm{M} \pm 1.74), \mathrm{OXA}(1.25 \mu \mathrm{M} \pm 1.56)$ and $\mathrm{MF}(4.55 \mu \mathrm{M} \pm 2.65)$. Dose-response curves of A549 cells were mostly in-between other NSCLC cell lines. The cells were most resistant to MF (17.86 $\mu \mathrm{M} \pm 1.32)$ and most sensitive to OXA (3.08 $\mu \mathrm{M} \pm 0.56)$. Overall, these data demonstrate divergent sensitivity of NSCLC cell lines to different chemotherapeutic agents. Therefore, in order to compare the immunogenic potential of the chemotherapeutic agent in our panel of NSCLC cell lines, the different IC50-72h values per cell line were used in further experiments. Because we determined the IC50 values over a timeframe of $72 \mathrm{~h}$ of treatment, the sequential order of the DAMPs was evaluated over this period of time. 


\subsection{Release of DAMPs by NSCLC Cell Lines after Chemotherapy}

\subsubsection{ATP Secretion}

First, ATP secretion was assessed $24 \mathrm{~h}$ after treatment with chemotherapy in all NSCLC cell lines (Figure 2).

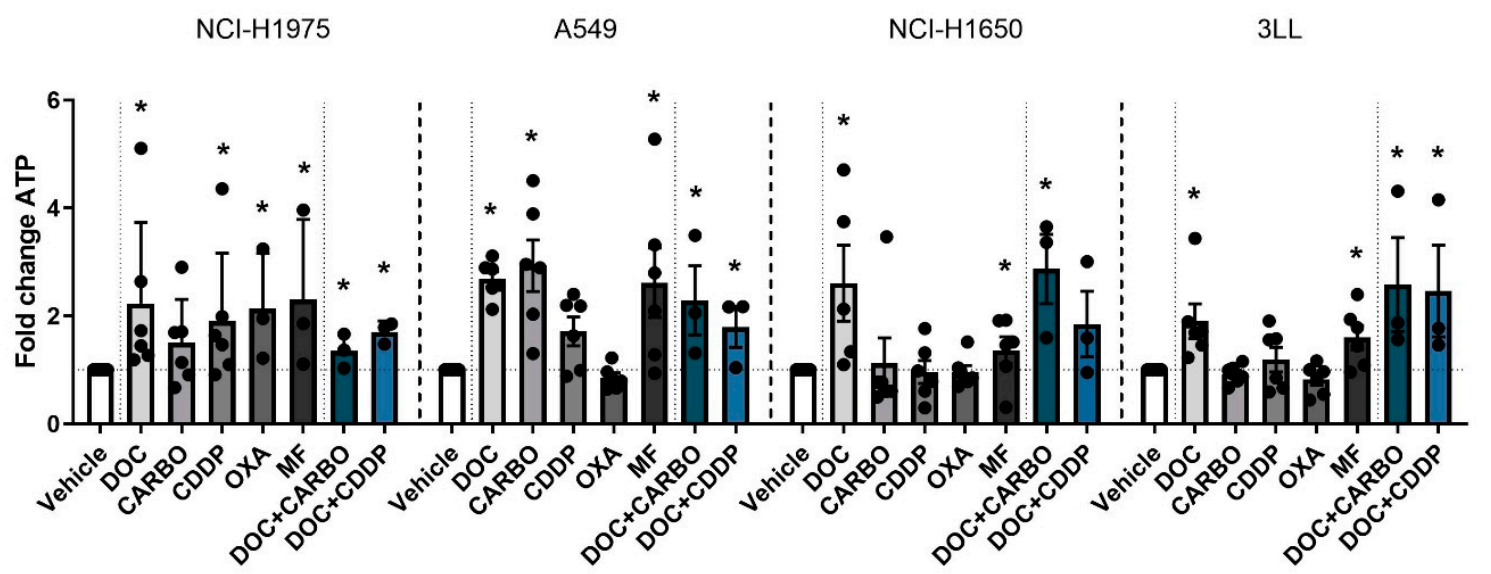

Figure 2. ATP secretion in NSCLC cell lines after treatment with chemotherapy. Early release of ATP was assessed after $24 \mathrm{~h}$ of treatment with the $\mathrm{IC}_{50}-72 \mathrm{~h}$ of docetaxel (DOC), carboplatin (CARBO), cisplatin (CDDP), oxaliplatin (OXA) and mafosfamide (MF) or treatment with the $\mathrm{IC}_{50}-72 \mathrm{~h}$ of DOC and $\mathrm{IC}_{40}-72 \mathrm{~h}$ value of either CARBO or CDDP in the NCI-H1975, A549, NCI-H1650 and 3LL cell line. ${ }^{*} p \leq 0.05$. Error bars represent the standard deviation. Experiments were performed at least in triplicate.

In the NCI-H1975 cell line treatment with all chemotherapies showed a significant 2-fold increase of ATP secretion compared to vehicle, except for treatment with CARBO. A549 cells treated with DOC, CARBO, MF and the two combination regimens showed a 2- to 3-fold significant increase of ATP compared to vehicle, with exception of CDDP and OXA. In NCI-H1650 cells, ATP levels were significantly increased after treatment with DOC, MF and the combination of DOC + CARBO by 2to 4 -fold compared to vehicle. Along the same line, murine 3LL cells treated with DOC, MF and the combination regimens showed a significant 2-fold increase of ATP secretion.

Overall, in all NSCLC cells lines, treatment with DOC, MF and DOC + CARBO induced significantly higher levels of ATP compared to vehicle. In addition, three out of the four NSCLC cell lines treated with DOC + CDDP resulted in a significant higher release of ATP compared to vehicle. However, no significant differences were found between the different chemotherapies.

\subsubsection{Ecto-CALR Exposure}

Next, ecto-CALR exposure on NSCLC cells was assessed after $48 \mathrm{~h}$ of treatment with chemotherapy in all four NSCLC cell lines (Figure 3, Figure S2). For this, NSCLC cell staining was performed with AnnV/PI to gate on non-permeabilized cells (Figure S3). In NCI-H1975 cells, treatment with all chemotherapeutic agents significantly increased percentages of ecto-CALR positive cells compared to vehicle, ranging from $1 \%$ up to $8 \%$ (Figure 3). In the A549 cell line treatment with DOC, DOC + CARBO and DOC + CDDP significantly increased ecto-CALR positive cells compared to vehicle, although this increase was less pronounced compared to other cell lines. Similar to NCI-H1975, all chemotherapies significantly increased ecto-CALR positive cells in the NCI-H1650 cell line compared to vehicle, with exception of MF. In addition, a more pronounced increase of ecto-CALR positive cells was observed in murine 3LL cells, which significantly increased ecto-CALR positive cells after treatment with all chemotherapies except for OXA, ranging from $10 \%$ up to $40 \%$ of ecto-CALR positive cells compared to vehicle. 
$\mathrm{NCl}-\mathrm{H} 1975$

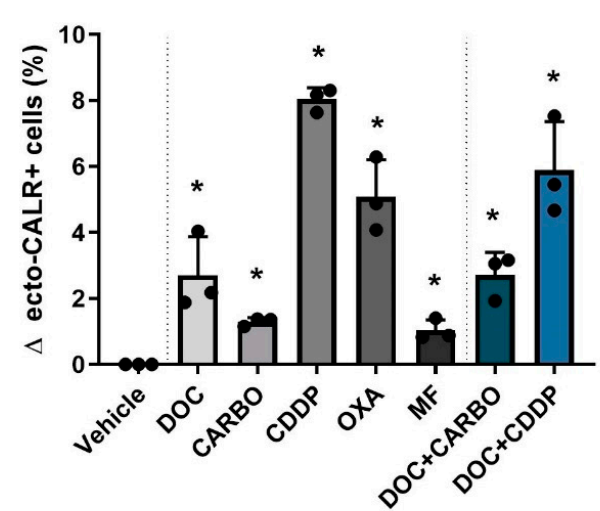

$\mathrm{NCl}-\mathrm{H} 1650$

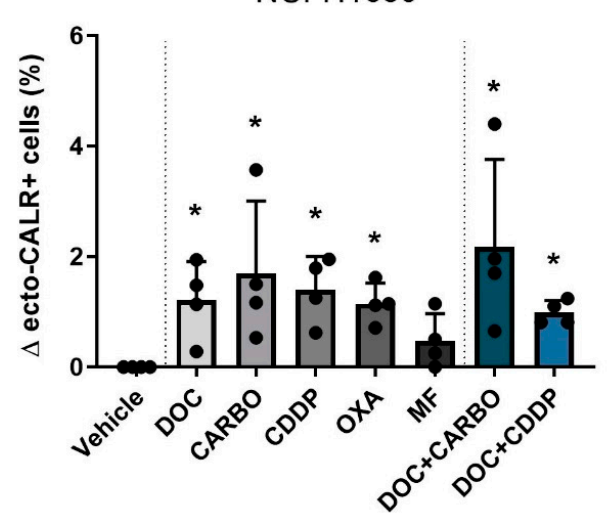

A549

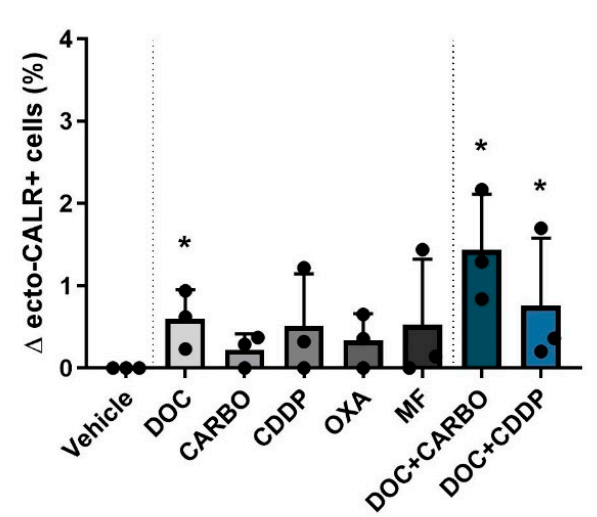

$3 \mathrm{LL}$

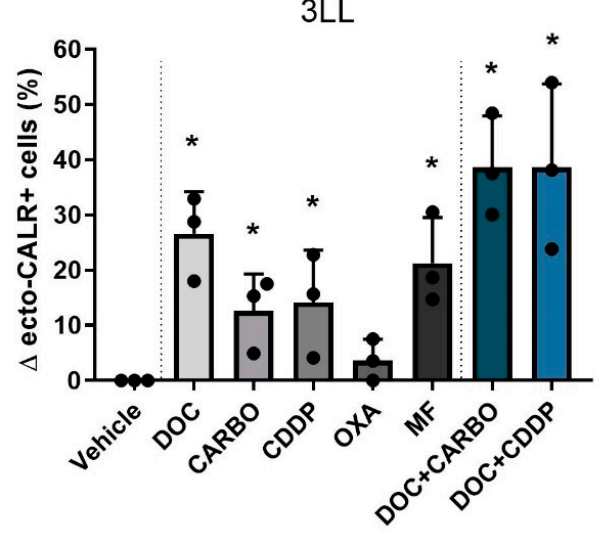

Figure 3. Ecto-CALR exposure in NSCLC cell lines after treatment with chemotherapy. Percentages of ecto-CALR positive (ecto-CALR+) cells were assessed after $48 \mathrm{~h}$ of treatment with the $\mathrm{IC}_{50}-72 \mathrm{~h}$ of docetaxel (DOC), carboplatin (CARBO), cisplatin (CDDP), oxaliplatin (OXA) and mafosfamide (MF) or treatment with the $\mathrm{IC}_{50}-72 \mathrm{~h}$ of DOC and $\mathrm{IC}_{40}-72 \mathrm{~h}$ value of either CARBO or CDDP in the NCI-H1975, A549, NCI-H1650 and 3LL cell line. ${ }^{*} p \leq 0.05$. Error bars represent the standard deviation. Experiments were performed at least in triplicate.

Overall, DOC, as monotherapy or in combination regimens, significantly increased ecto-CALR positive cells in all NSCLC cell lines. Moreover, treatment with DOC + CDDP showed higher \%ecto-CALR positive cells compared to treatment with DOC and DOC + CARBO in the NCI-H1675 cell line $(p \leq 0.05)$. No significant differences between treatment with DOC, DOC + CARBO and DOC + CDDP were found in the other NSCLC cell lines.

\subsubsection{HMGB1 Release}

Finally HMGB1 release was assessed after $72 \mathrm{~h}$ of treatment with chemotherapy in all four NSCLC cell lines (Figure 4). In the NCI-H1975 cell line, HMGB1 release was significantly increased compared to vehicle after treatment with $\mathrm{DOC}, \mathrm{DOC}+\mathrm{CARBO}$ and DOC + CDDP, with the latter reaching a nearly 4 -fold increase compared to vehicle. Both combination strategies showed significantly higher amounts of HMGB1 compared to treatment with DOC ( $p \leq 0.05)$. Similarly, A549 cells treated with DOC, DOC + CARBO and DOC + CDDP significantly increased HMGB1 release. Both combinations resulted in significantly higher levels of HMGB1 compared to treatment with DOC $(p \leq 0.05)$. In NCI-H1650 cells, only treatment with DOC + CARBO and DOC + CDDP showed a significant 2-fold increase of HMGB1, both at similar levels. Moreover, 3LL cells showed a significant 2- to 4-fold increase of HMGB1 release after treatment with all chemotherapies compared to vehicle, with exception of OXA. 


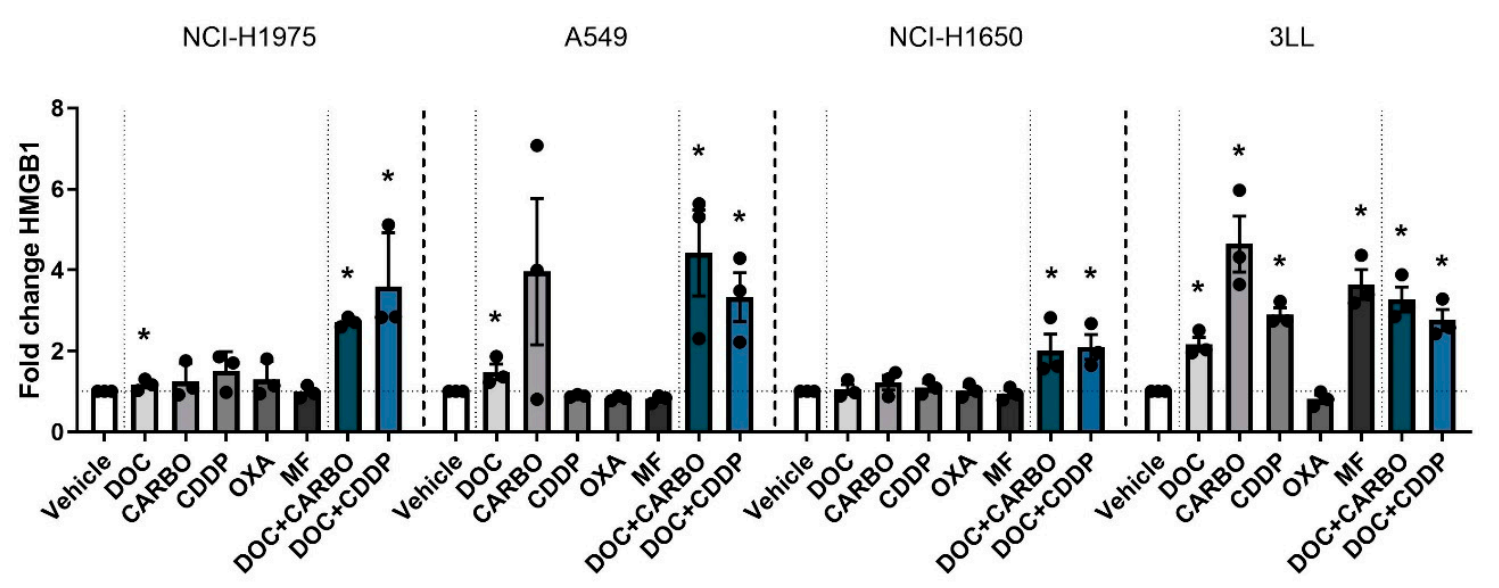

Figure 4. HMGB1 release in NSCLC cell lines after treatment with chemotherapy. Release of HMGB1 $(\mathrm{ng} / \mathrm{mL})$ was assessed after $72 \mathrm{~h}$ of treatment with the $\mathrm{IC}_{50}-72 \mathrm{~h}$ of docetaxel (DOC), carboplatin (CARBO), cisplatin (CDDP), oxaliplatin (OXA) and mafosfamide (MF) or treatment with the $\mathrm{IC}_{50}-72 \mathrm{~h}$ of DOC and $\mathrm{IC}_{40}-72 \mathrm{~h}$ value of either CARBO or CDDP in the NCI-H1975, A549, NCI-H1650 and 3LL cell line and is depicted as fold change. ${ }^{*} p \leq 0.05$. Error bars represent the standard deviation. Experiments were performed in triplicate.

Overall, in all NSCLC cell lines, both DOC + CARBO and DOC + CDDP significantly increased HMGB1 levels compared to vehicle.

\subsection{Phagocytic Function and Maturation Status after Chemotherapy Treatment of NSCLC Cell Lines}

Phagocytosis of dying tumor cells and subsequent maturation of DCs is a crucial step in the process of establishing an adequate anti-tumor immune response [37]. To this end, human NCI-H1975, A549 and NCI-H1650 cells were treated with the different chemotherapies and were subsequently co-cultured with immature DCs of three healthy donors in order to assess their phagocytotic ability and maturation status (CD80 and CD86). First, potential cytotoxic effects of the chemotherapeutic agents on DC viability were evaluated. Treated DCs showed no difference in viability compared to their untreated (PBS) counterparts (Figure S4). Furthermore, co-cultures of NSCLC cells and DCs resulted in phagocytosis of treated NSCLC cells at varying levels depending on the cell line and on the chemotherapy (Figure 5). Overall treatment with DOC, DOC + CARBO and DOC + CDDP resulted in phagocytosis of NSCLC cells by DCs in all NSCLC cell lines.

In addition, maturation markers were upregulated on DCs after chemotherapy treatment at varying levels with CD86 expression being overall more pronounced than CD80 (shown as $\triangle \mathrm{MFI}$ ). Importantly, expression of CD80 and CD86 on monocultured DCs treated with the chemotherapeutic agents did not significantly differ from vehicle (Figures S4 and S5), indicating that the immunogenic effects of chemotherapy rely on their interaction with tumor cells. In the NCI-H1975 cell line, CD80 was significantly upregulated on DCs after treatment with CDDP and OXA. Similarly, CD86 was upregulated after CDDP treatment as opposed to the latter. Moreover, DOC, CARBO and the two combinations significantly upregulated CD86 on DCs in co-culture with NCI-H1975 cells. While DCs in co-culture with A549 cells only showed an upregulation of CD80 after treatment with DOC and CARBO, CD86 expression was significantly upregulated on DCs after treatment with all chemotherapies compared to vehicle. There were no statistical significant differences found in CD86 expression on DCs between the different chemotherapies. Co-cultures of DCs with NCI-H1650 cells showed a more pronounced upregulation of CD80 on DCs compared to the other cell lines. In the NCI-H1650 cell line, CD80 was significantly upregulated on DCs after treatment with CARBO, OXA, MF and both combination regimens compared to vehicle. Maturation marker CD86 was significantly upregulated after treatment with all chemotherapies, except for MF. 
A

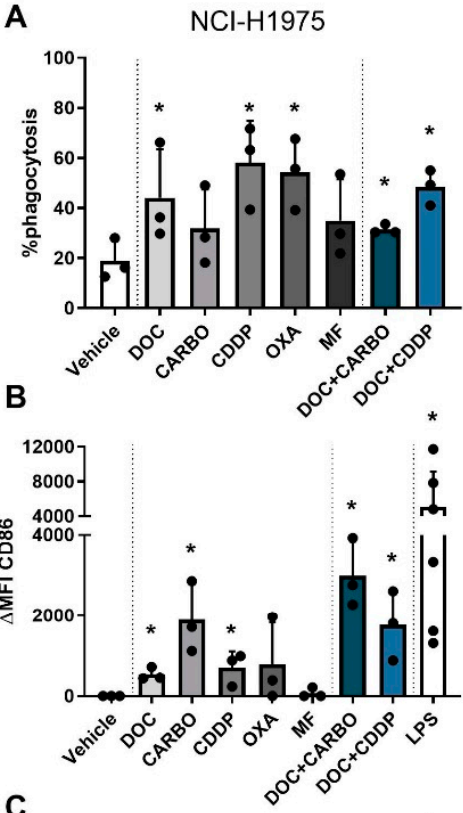

C

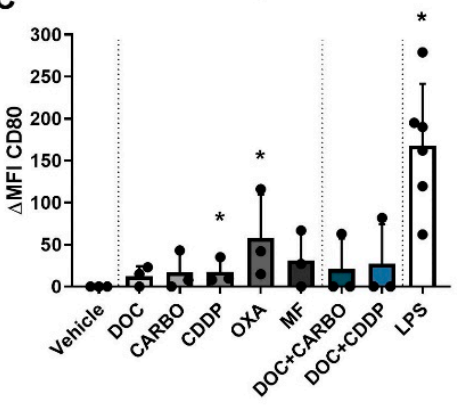

A549
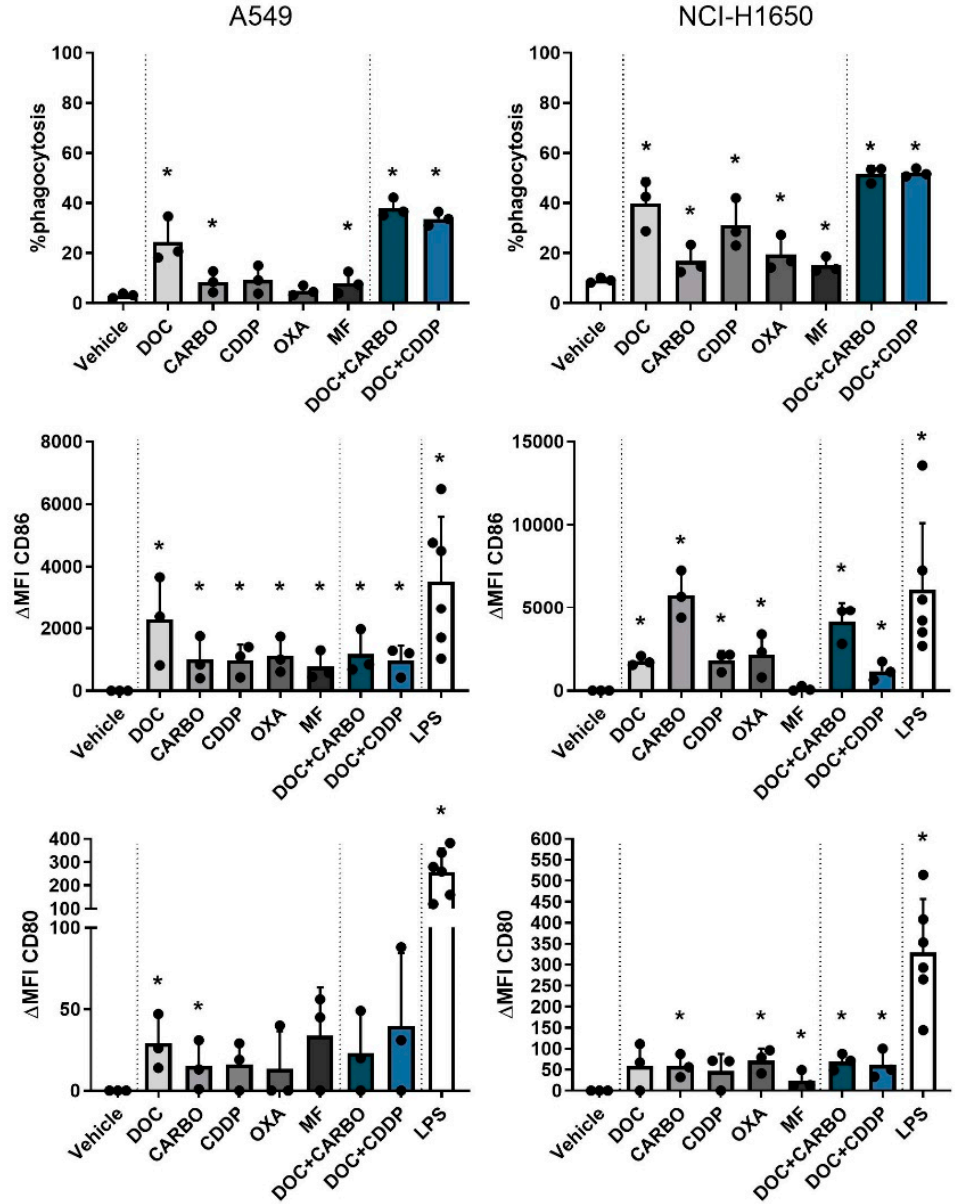

$\mathrm{NCl}-\mathrm{H} 1650$
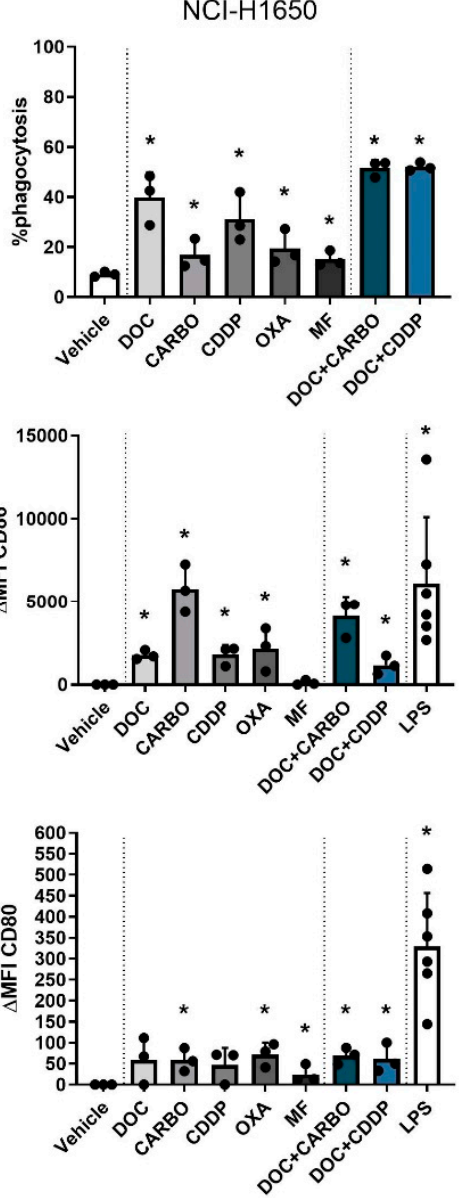

Figure 5. Phagocytic ability and maturation status of DCs in co-culture with different NSCLC cell lines after treatment with chemotherapy. (A) Phagocytosis of treated NSCLC cells by DCs and maturation markers (B) CD86 and (C) CD80 of DCs were assessed after $72 \mathrm{~h}$ of treatment with the $\mathrm{IC}_{50}-72 \mathrm{~h}$ of docetaxel (DOC), carboplatin (CARBO), cisplatin (CDDP), oxaliplatin (OXA) and mafosfamide (MF) or treatment with the $\mathrm{IC}_{50}-72 \mathrm{~h}$ of DOC and $\mathrm{IC}_{40}-72 \mathrm{~h}$ value of either CARBO or CDDP in the NCI-H1975, A549 and NCI-H1650 cell line. Data of maturation markers are expressed as delta mean fluorescence intensity $(\triangle \mathrm{MFI})$, which was calculated by subtracting the isotype control of each condition and vehicle (PBS), respectively. ${ }^{*} p \leq 0.05$. Error bars represent the standard deviation. Experiments were performed in triplicate.

Overall, in all NSCLC cell lines upregulation of CD86 was more pronounced compared to CD80 and significantly upregulated after treatment with DOC, CARBO, CDDP, DOC + CARBO and DOC + CDDP compared to vehicle.

Since immunosuppressive cytokines, such as transforming growth factor- $\beta$ (TGF- $\beta$ ) are largely produced within the tumor microenvironment, its secretion in co-cultures was measured and shown as foldchange relative to control (concentrations ranging from 300-3000 pg/mL; Suppl. Methods). In the co-culture with NCI-H1975 cells, TGF- $\beta$ levels were significantly lower after treatment with DOC, CARBO, OXA and DOC + CARBO compared to vehicle. Similarly, co-cultures with A549 cells showed significantly lower levels of TGF- $\beta$ after treatment with DOC, CARBO, OXA, DOC + CARBO as well as DOC + CDDP compared to vehicle. In addition, TGF- $\beta$ levels were significantly lower compared to vehicle in co-cultures with NCI-H1650 cells after treatment with these above-mentioned chemotherapeutic regimens, with exception of CARBO.

In addition to TGF- $\beta$, secretion of immunostimulatory cytokines interferon- $\beta$ (IFN- $\beta$ ), tumor necrosis factor- $\alpha$ (TNF- $\alpha$ ) and IL- 6 were assessed in the co-cultures. In case of IFN $\beta$, its secretion 
in the $\mathrm{SN}$ of different treatment groups was not significantly higher compared to vehicle, except for co-cultures of NCI-H1975 cells treated with DOC + CDDP. Secretion of IL-6 was significantly higher in co-cultures of NCI-H1975 treated with each treatment regimen compared to vehicle, with exception of MF. In case of TNF $\alpha$, both co-cultures with A549 and NCI-H1650 cells showed significantly higher levels after treatment with DOC and CDDP compared to vehicle. In addition, A549 cells treated with OXA and DOC + CDDP showed significantly higher levels of TNF $\alpha$ secretion compared to vehicle as well (Figure S6).

\subsection{Overview of DAMPs and DC Phagocytic Function and Maturation Status after Chemotherapy Treatment of NSCLC Cell Lines}

An overview of all data of in vitro assessment of DAMPs, phagocytosis and maturation of DCs in all NSCLC cell lines is depicted in Figure 6. Three out of four NSCLC cell lines (NCI-H1975, A549 and 3LL) showed significantly higher levels of ATP, ecto-CALR and HMGB1 after treatment with DOC, DOC + CARBO and DOC + CDDP compared to vehicle. In addition, phagocytosis of treated NSCLC cells and maturation (CD86) of DCs were significantly increased in all three human NSCLC cell lines after treatment with the above-mentioned chemotherapeutic regimens. Furthermore, murine 3LL cells treated with DOC, MF, DOC + CARBO and DOC + CDDP resulted in a significant release of all three DAMPs in vitro, as opposed to treatment with OXA.
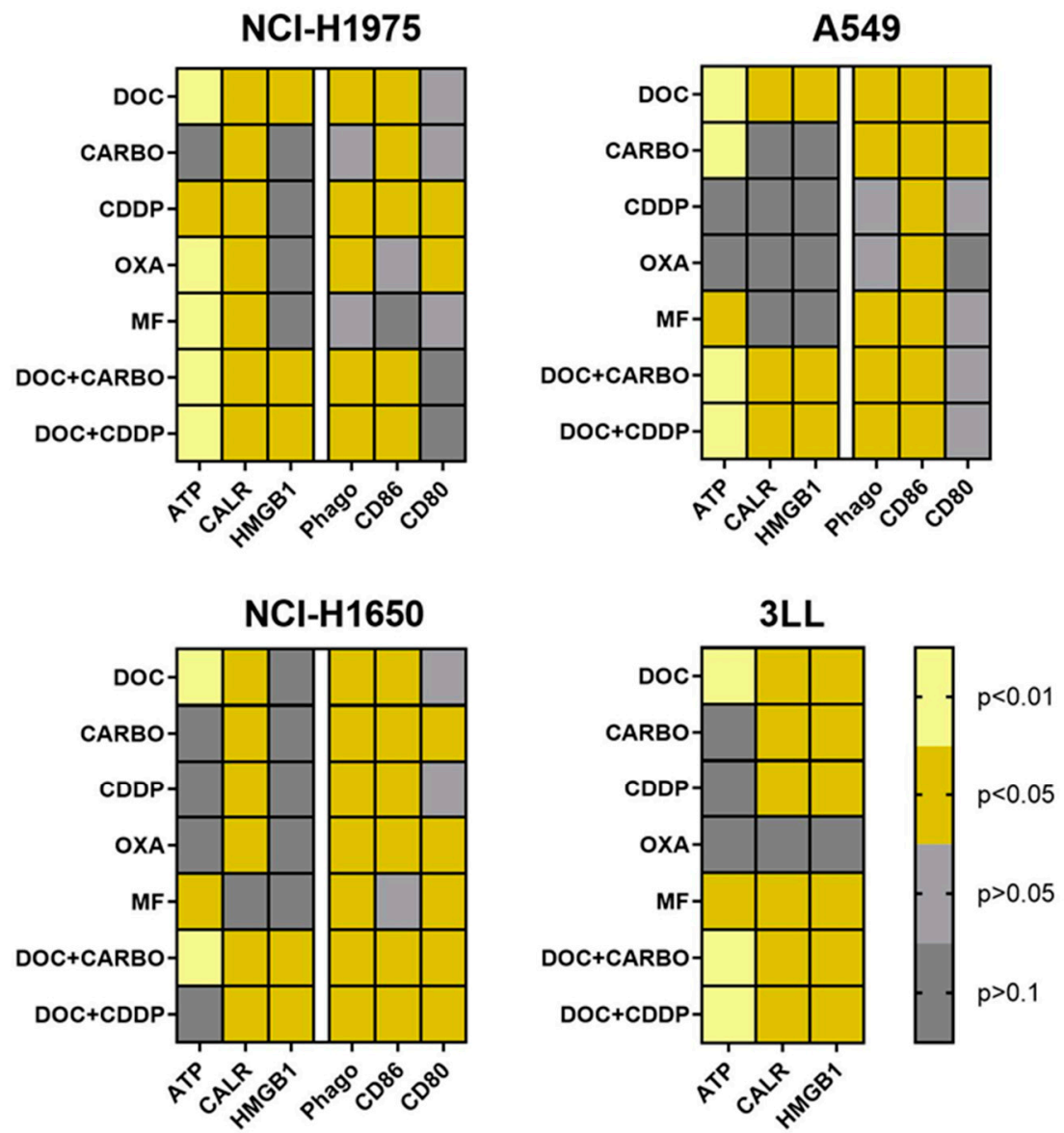

Figure 6. Heatmap overview of DAMPs, phagocytic ability and maturation status of DCs. An overview of the $p$-values of DAMPs is shown for cell lines NCI-H1975, A549, NCI-H1650 and 3LL. Phagocytic ability and maturation status of DCs is shown for cell lines NCI-H1975, A549 and NCI-H1650. Light yellow: $p \leq 0.01$; dark yellow: $p \leq 0.05$ (if increased compared to vehicle); light grey: $p>0.05$; dark grey: $p>0.1$. 


\subsection{In Vivo Vaccination Assay in the 3LL Mouse Model}

The in vitro experiments can give valuable insights into the potential of therapeutic agents to mount an effective anti-tumor immune response, although these assays do not take a complete immune system into account. Hence, we performed a vaccination experiment in C57BL/6J mice with murine 3LL cells in order to validate our in vitro results. Mice were vaccinated twice with (un)treated 3LL cells, subsequently challenged with live 3LL cells and then monitored for tumor growth during 60 days. All mice's weight remained stable throughout the entire follow-up period. Percentage of tumor-free mice and follow-up of tumor growth are depicted in Figure 7.

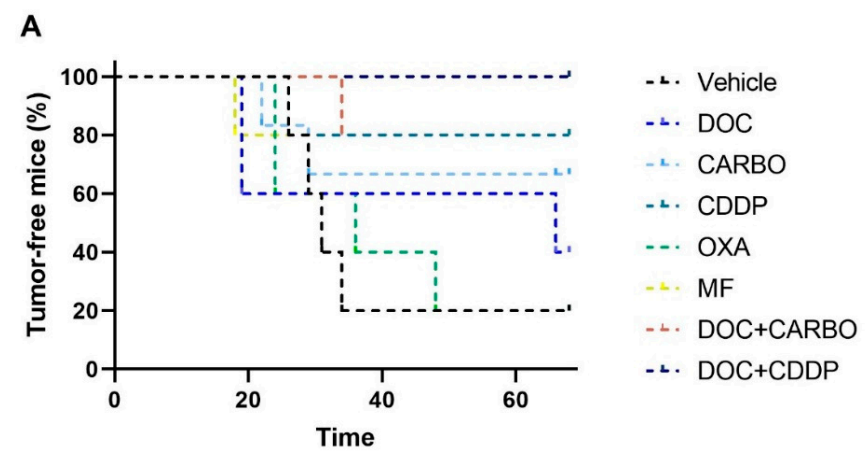

B
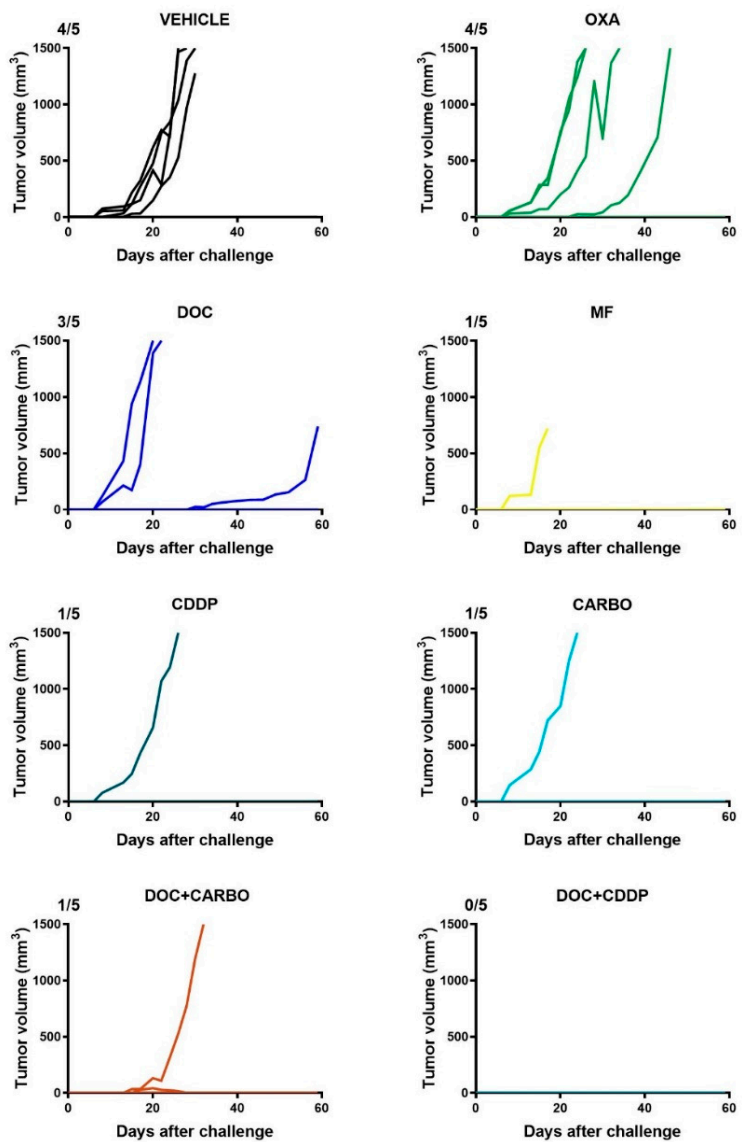

Figure 7. In vivo vaccination underscores immunogenic capacity of clinically relevant chemotherapeutics in the 3LL mouse model. (A) Percentage (\%) of tumor-free mice and (B) follow-up of tumor growth $\left(\mathrm{mm}^{3}\right)$ of $\mathrm{C} 57 \mathrm{BL} / 6 \mathrm{~J}$ mice for 60 days or until endpoint was reached (volume $\geq 1500 \mathrm{~mm}^{3}$ ). Five mice were assigned to each condition: Vehicle (PBS), docetaxel (DOC), carboplatin (CARBO), cisplatin (CDDP), oxaliplatin (OXA) and mafosfamide (MF), DOC + CARBO or DOC + CDDP. Ratios on top of each graph represent the number of mice that developed a tumor during the follow-up period. 
Four out of five mice $(80 \%)$ from the control group developed a tumor at the challenge site. Similarly, four out of five mice $(80 \%)$ vaccinated with OXA-treated cells developed a tumor at the challenge site. Furthermore, three out of five mice $(60 \%)$ vaccinated with DOC-treated cells developed a tumor at the challenge site. Mice vaccinated with CARBO, CDDP, MF and DOC + CARBO developed a tumor in only one out of five mice (20\%). Notably, the tumor-bearing MF mouse failed to reach the endpoint of $1500 \mathrm{~mm}^{3}$ tumor volume due to early death (unknown cause). Furthermore, five out of five mice $(100 \%)$ vaccinated with DOC + CDDP remained tumor-free during the entire follow-up period. A trend towards significant differences was observed between survival probabilities of the different groups (Log-rank test, $p=0.079$ ).

\section{Discussion}

The ability of chemotherapy to elicit ICD has become a thoroughly investigated phenomenon, in both in vitro and in vivo settings [16,37]. To this end, we demonstrated that clinically relevant chemotherapeutic regimens for NSCLC can exert immunostimulatory effects in different NSCLC cell lines. Especially, DOC, DOC + CARBO and DOC + CDDP resulted in a significant increase of DAMPs and maturation of DCs in NSCLC cell lines in vitro. As opposed to DOC alone, combination regimens of DOC + CARBO and DOC + CDDP showed similar findings in an in vivo vaccination assay resulting in $80 \%$ and $100 \%$ tumor-free mice, respectively.

OXA, CARBO and CDDP all belong to the platinum-derived compounds and are cytotoxic by forming inter- and intra-strand DNA adducts [38]. Many articles performing research on the ability of chemotherapeutic agents to induce ICD report that CDDP is a negative control due to its inability to trigger ER stress, and hence its incapacity to promote CALR translocation from the ER lumen to the outer leaflet of the plasma membrane [39]. Contrarily, CDDP has also been described to exert pleiotropic effects, including induction of ER stress [40-43]. Ecto-CALR exposure on the membrane of (dying) tumor cells is important for recognition and engulfment by DCs, leading to optimal antigen presentation to $\mathrm{T}$ cells, hence activating an adaptive anti-tumor immune response [25]. Activation of the ER stress response is characterized by phosphorylation of the eukaryotic translation initiation factor $2 \alpha$ (eIF2 $\alpha$ ) by protein kinase-like ER kinase (PERK). Once activated, sequential activation of caspase- 8 and cleavage of the ER protein (BAP31) is triggered, leading to CALR translocation from the ER to exposure on the cell surface [25].

One study showed that the $\mathrm{IC}_{50}$ of CDDP and OXA were both able to induce nuclear apoptosis and ATP release at similar levels. However, OXA induced higher phosphorylation of eIF2 $\alpha$ and thus higher CALR levels compared to CDDP using U2OS cells, an osteosarcoma cell line. In addition, they showed that OXA-treated 3LL cells triggered higher ecto-CALR levels compared to CDDP-treated 3LL cells [39]. Contrary to their results, we observed significantly higher ecto-CALR levels in 3LL cells treated with CDDP compared to OXA-treated cells. While the study of Tesniere et al. treated cells with $300 \mu \mathrm{M}$ of OXA and $150 \mu \mathrm{M}$ of CDDP, we only used $1.25 \mu \mathrm{M}$ and $1.92 \mu \mathrm{M}\left(\mathrm{IC}_{50}\right.$ value determined as described in materials \& methods), respectively, which might explain these discrepancies. Another possible explanation underlying these interstudy discrepancies is reported to be the production of IL-8 by various cancer cells. Sukkurwala et al. showed that cancer cells that produce high amounts of IL-8 in response to immunogenic chemotherapies stimulate CALR exposure [44]. In this regard, previous studies reported that certain cancer cells, including the NSCLC cell line A549, constitutively produce high levels of IL-8 [45,46], thus induction of ecto-CALR exposure in this cell line would only seem plausible. However, in our study A549 cells showed quite low \%ecto-CALR positive cells after $48 \mathrm{~h}$ treatment with DOC, DOC + CARBO and DOC + CDDP. These interstudy discrepancies might be due to differences between concentrations used and/or duration of the treatment [47].

Another study showed that OXA, but not CDDP could trigger eco-CALR exposure using murine and human colon cancer cell lines, although both compounds resulted in HMGB1 release at similar levels [30]. Similarly, we observed that both CDDP- and OXA-treated NSCLC cells could trigger HMGB1 release. Moreover, both CDDP and OXA treatments showed phagocytosis of NSCLC cells by 
DCs and upregulation of maturation markers on DCs, although at varying levels among the different NSCLC cell lines. Our results are in line with previous studies showing increased tumor cell uptake and upregulation of maturation markers CD80 and CD86 on different subsets of human blood DCs after treatment with CDDP and OXA [48]. Since CDDP and OXA are thoroughly studied in the context of ICD, one would expect that treatment with other platinum analogs, such as CARBO could exert immunogenic effects on the tumor and its micro-environment as well. Indeed, in our study CARBO induced DAMPs and led to upregulation of maturation markers on DCs at varying levels.

To date, data on the ability of CARBO to induce ICD are quite limited. While one study reported that CARBO did not significantly increase ecto-CALR exposure and HMGB1 release in TSA cells (mouse mammary adenocarcinoma), another study reported its ability to induce ecto-CALR exposure and HMGB1 release in murine colon cancer cells [49,50].

Furthermore, MF has been reported to induce ecto-CALR exposure and HMGB1 release in vitro. Its immunogenic potential was confirmed in an in vivo vaccination assay using OVA-expressing EG7 thymoma cells [51]. Along similar lines, Du. et al. reported that this activated derivative of CP induced a robust type I interferon response and vaccinated mice against GL261 glioma cells [52]. Our study showed that induction of DAMPs varied between different NSCLC cell lines after treatment with MF. Although in murine 3LL cells, MF treatment resulted in a significant increase of all DAMPs which was consistent with in vivo findings in which $80 \%$ of the mice remained tumor-free.

Only a few studies reported induction of DAMPs after treatment with DOC, a tubulin stabilizing agent, which belongs to the taxane family. The study of Gao et al. showed that DOC treatment significantly upregulated HMGB1 release in human NSCLC cell lines and that HMGB1 levels correlated with improved outcomes in NSCLC patients [53]. Contrarily, Hodge et al. reported that DOC was only able to induce ecto-CALR exposure in human breast, prostate and colorectal carcinoma [54]. In our study, the most consistent treatment among all NSCLC cell lines was DOC, DOC + CARBO and DOC + CDDP.

Finally, we performed a vaccination assay using 3LL cells in an attempt to validate our in vitro and in vivo findings. 3LL cells treated with OXA failed to induce any of the DAMPs, hence it was not surprising that only $20 \%$ of the mice vaccinated with OXA were tumor-free. On the other hand, DOC treatment of 3LL cells induced all DAMPs, but only $40 \%$ of the mice vaccinated with DOC remained tumor-free. As opposed to DOC alone, combinations with CARBO or CDDP induced all DAMPs in vitro and resulted in $80 \%$ and $100 \%$ tumor-free mice, respectively. Of note, it is important to mention that although the in vivo vaccination assay remains the gold-standard to confirm ICD up to date, human and murine NSCLC data should be carefully interpreted due to differences between human and murine NSCLC cells in terms of immunogenicity [55].

Whether there is a hierarchical order of importance regarding these DAMPs is not yet clear, although one study assessed the relevance of these DAMPs [56]. Garg et al. blocked each of the DAMPs in vivo and showed that they differ in relevance, based on survival data: the most relevant DAMP was HMGB1, followed by ATP and finally ecto-CALR being the least relevant. Although our in vitro findings demonstrated that DOC induced all DAMPs in 3LL cells, HMGB1 secretion was significantly lower in DOC-treated or OXA-treated cells compared to all other treatments, which might explain why these mice developed a tumor after all.

Recent data on clinical trials of combination strategies with chemotherapy and immunotherapy in NSCLC patients support the idea of including a chemotherapeutic regimen to immunotherapy to mount an effective anti-tumor immune response $[57,58]$. Thus, obtaining valuable insights into these immunogenic properties paves the way towards more rationally designed combination strategies to optimize clinical outcomes of NSCLC patients. 


\section{Conclusions}

In conclusion, with this study we provide novel in vitro and in vivo data on the immunostimulatory effects of clinically relevant chemotherapeutic regimens in NSCLC, with the best results for DOC + CARBO and DOC + CDDP.

Supplementary Materials: The following are available online at http://www.mdpi.com/2073-4409/9/6/1474/s1, Figure S1: Dose-response curves of pemetrexed in human NSCLC cell lines, Figure S2: Gating strategy of ecto-CALR ${ }^{+}$cells in NSCLC cell lines, Figure S3: NSCLC cell staining with AnnV/PI after $24 \mathrm{~h}$ and $48 \mathrm{~h}$ treatment with chemotherapy, Figure S4: DCs viability and maturation status after treatment with chemotherapy, Figure S5: Gating strategy of phagocytosis of NSCLC cells and DC maturation, Figure S6: Cytokine secretion in supernatant from co-cultures of NSCLC cells and DCs after treatment with chemotherapy.

Author Contributions: Conceptualization, T.F., J.J.; methodology, T.F., J.J., J.V.L. and E.S.; formal analysis, T.F.; investigation, T.F., J.V.L., L.F.B., J.D.W. and J.V.A.; writing-original draft preparation, T.F.; writing-review and editing, L.F.B., A.V.d.E., J.V.L., J.V.A., J.D.W., F.L., E.S., P.P., J.J.; visualization, T.F.; supervision, J.J., E.S., P.P.; project administration, J.J., E.S. and P.P. All authors have read and agreed to the published version of the manuscript.

Funding: This research was funded by the University of Antwerp, grant number FFB180180 and FFB160231; Kom op tegen Kanker (Stand up to Cancer), the Flemish cancer society, grant number OZ7878, OZ8107 and OZ7267; Kom op tegen Kanker (Stand up to Cancer), the Flemish cancer society, Emmanuel van der Schueren fellowship, grant number 16268; Research Foundation Flanders, FWO, grant number 1121016N, 11E7719N and $1 \mathrm{~S} 32316 \mathrm{~N}$. The APC was funded by Kom op tegen Kanker (Stand up to Cancer).

Acknowledgments: The authors express their gratitude to Céline Merlin, Christophe Hermans, Hilde Lambrechts, Eva Lion and Hans de Reu for technical assistance; to VITO for the use of the MSD reader (Mol, Belgium). The authors also thank the Vereycken family, Willy Floren and the University Foundation of Belgium for their financial support.

Conflicts of Interest: The authors declare no conflict of interest.

\section{References}

1. Bray, F.; Ferlay, J.; Soerjomataram, I.; Siegel, R.L.; Torre, L.A.; Jemal, A. Global cancer statistics 2018: GLOBOCAN estimates of incidence and mortality worldwide for 36 cancers in 185 countries. CA Cancer J. Clin. 2018, 68, 394-424. [CrossRef] [PubMed]

2. Torre, L.A.; Bray, F.; Siegel, R.L.; Ferlay, J.; Lortet-Tieulent, J.; Jemal, A. Global cancer statistics, 2012. CA Cancer J. Clin. 2015, 65, 87-108.

3. Collins, L.G.; Haines, C.; Perkel, R.; Enck, R.E. Lung cancer: Diagnosis and management. Am. Fam. Physician 2007, 75, 56-63.

4. Hirsh, V. Systemic therapies in metastatic non-small-cell lung cancer with emphasis on targeted therapies: The rational approach. Curr. Oncol. 2010, 17, 13-23. [CrossRef]

5. Burugu, S.; Dancsok, A.R.; Nielsen, T.O. Emerging targets in cancer immunotherapy. Semin. Cancer Biol. 2018, 52, 39-52.

6. Reck, M.; Rodriguez-Abreu, D.; Robinson, A.G.; Hui, R.; Csoszi, T.; Fulop, A.; Gottfried, M.; Peled, N.; Tafreshi, A.; Cuffe, S.; et al. Updated Analysis of KEYNOTE-024: Pembrolizumab Versus Platinum-Based Chemotherapy for Advanced Non-Small-Cell Lung Cancer With PD-L1 Tumor Proportion Score of 50\% or Greater. J. Clin. Oncol. 2019, 37, 537-546. [CrossRef]

7. Larkin, J.; Chiarion-Sileni, V.; Gonzalez, R.; Grob, J.-J.; Rutkowski, P.; Lao, C.D.; Cowey, C.L.; Schadendorf, D.; Wagstaff, J.; Dummer, R.; et al. Five-Year Survival with Combined Nivolumab and Ipilimumab in Advanced Melanoma. N. Engl. J. Med. 2019, 381, 1535-1546. [CrossRef]

8. Motzer, R.J.; Escudier, B.; McDermott, D.F.; George, S.; Hammers, H.J.; Srinivas, S.; Tykodi, S.S.; Sosman, J.A.; Procopio, G.; Plimack, E.R.; et al. Nivolumab versus Everolimus in Advanced Renal-Cell Carcinoma. N. Engl. J. Med. 2015, 373, 1803-1813. [CrossRef]

9. Seiwert, T.Y.; Burtness, B.; Mehra, R.; Weiss, J.; Berger, R.; Eder, J.P.; Heath, K.; McClanahan, T.; Lunceford, J.; Gause, C.; et al. Safety and clinical activity of pembrolizumab for treatment of recurrent or metastatic squamous cell carcinoma of the head and neck (KEYNOTE-012): An open-label, multicentre, phase $1 \mathrm{~b}$ trial. Lancet. Oncol. 2016, 17, 956-965. [CrossRef] 
10. Balar, A.V.; Castellano, D.; O’Donnell, P.H.; Grivas, P.; Vuky, J.; Powles, T.; Plimack, E.R.; Hahn, N.M.; de Wit, R.; Pang, L.; et al. First-line pembrolizumab in cisplatin-ineligible patients with locally advanced and unresectable or metastatic urothelial cancer (KEYNOTE-052): A multicentre, single-arm, phase 2 study. Lancet. Oncol. 2017, 18, 1483-1492. [CrossRef]

11. Chen, R.; Zinzani, P.L.; Fanale, M.A.; Armand, P.; Johnson, N.A.; Brice, P.; Radford, J.; Ribrag, V.; Molin, D.; Vassilakopoulos, T.P.; et al. Phase II Study of the Efficacy and Safety of Pembrolizumab for Relapsed/Refractory Classic Hodgkin Lymphoma. J. Clin. Oncol. 2017, 35, 2125-2132. [CrossRef] [PubMed]

12. Groenendijk, F.H. Drug resistance to targeted therapies: Déjà vu all over again. Mol. Oncol. 2014, 8, 1067-1083. [CrossRef] [PubMed]

13. Dammeijer, F.; Lau, S.P.; van Eijck, C.H.J.; van der Burg, S.H.; Aerts, J.G.J. V Rationally combining immunotherapies to improve efficacy of immune checkpoint blockade in solid tumors. Cytokine Growth Factor Rev. 2017, 36, 5-15. [CrossRef] [PubMed]

14. Jacobs, J.; Deschoolmeester, V.; Zwaenepoel, K.; Rolfo, C.; Silence, K.; Rottey, S.; Lardon, F.; Smits, E.; Pauwels, P. CD70: An emerging target in cancer immunotherapy. Pharmacol. Ther. 2015, 155, 1-10. [CrossRef]

15. Emens, L.A.; Middleton, G. The interplay of immunotherapy and chemotherapy: Harnessing potential synergies. Cancer Immunol. Res. 2015, 3, 436-443. [CrossRef]

16. Wang, Y.-J.; Fletcher, R.; Yu, J.; Zhang, L. Immunogenic effects of chemotherapy-induced tumor cell death. Genes Dis. 2018, 5, 194-203. [CrossRef]

17. Wu, J.; Waxman, D.J. Immunogenic chemotherapy: Dose and schedule dependence and combination with immunotherapy. Cancer Lett. 2018, 419, 210-221. [CrossRef]

18. Huang, X.; Cui, S.; Shu, Y. Cisplatin selectively downregulated the frequency and immunoinhibitory function of myeloid-derived suppressor cells in a murine B16 melanoma model. Immunol. Res. 2016, 64, 160-170. [CrossRef]

19. Micheau, O.; Solary, E.; Hammann, A.; Martin, F.; Dimanche-Boitrel, M.T. Sensitization of cancer cells treated with cytotoxic drugs to fas-mediated cytotoxicity. J. Natl. Cancer Inst. 1997, 89, 783-789. [CrossRef]

20. Gameiro, S.R.; Caballero, J.A.; Higgins, J.P.; Apelian, D.; Hodge, J.W. Exploitation of differential homeostatic proliferation of T-cell subsets following chemotherapy to enhance the efficacy of vaccine-mediated antitumor responses. Cancer Immunol. Immunother. 2011, 60, 1227-1242. [CrossRef]

21. Okita, R.; Yukawa, T.; Nojima, Y.; Maeda, A.; Saisho, S.; Shimizu, K.; Nakata, M. MHC class I chain-related molecule A and B expression is upregulated by cisplatin and associated with good prognosis in patients with non-small cell lung cancer. Cancer Immunol. Immunother. 2016, 65, 499-509. [CrossRef] [PubMed]

22. Palma, J.P.; Aggarwal, S.K. Cisplatin and carboplatin-mediated activation of murine peritoneal macrophages in vitro: Production of interleukin-1 alpha and tumor necrosis factor-alpha. Anticancer. Drugs 1995, 6, 311-316. [CrossRef] [PubMed]

23. Li, J.-Y.; Duan, X.-F.; Wang, L.-P.; Xu, Y.-J.; Huang, L.; Zhang, T.-F.; Liu, J.-Y.; Li, F.; Zhang, Z.; Yue, D.-L.; et al. Selective depletion of regulatory $\mathrm{T}$ cell subsets by docetaxel treatment in patients with nonsmall cell lung cancer. J. Immunol. Res. 2014, 2014, 286170. [CrossRef]

24. Chen, G.; Emens, L.A. Chemoimmunotherapy: Reengineering tumor immunity. Cancer Immunol. Immunother. 2013, 62, 203-216. [CrossRef] [PubMed]

25. Panaretakis, T.; Kepp, O.; Brockmeier, U.; Tesniere, A.; Bjorklund, A.-C.; Chapman, D.C.; Durchschlag, M.; Joza, N.; Pierron, G.; Yuan, J.; et al. Mechanisms of pre-apoptotic calreticulin exposure in immunogenic cell death. EMBO J. 2009, 28, 578-590. [CrossRef] [PubMed]

26. Apetoh, L.; Ghiringhelli, F.; Tesniere, A.; Criollo, A.; Ortiz, C.; Lidereau, R.; Mariette, C.; Chaput, N.; Mira, J.-P.; Delaloge, S.; et al. The interaction between HMGB1 and TLR4 dictates the outcome of anticancer chemotherapy and radiotherapy. Immunol. Rev. 2007, 220, 47-59. [CrossRef]

27. Showalter, A.; Limaye, A.; Oyer, J.L.; Igarashi, R.; Kittipatarin, C.; Copik, A.J.; Khaled, A.R. Cytokines in immunogenic cell death: Applications for cancer immunotherapy. Cytokine 2017, 97, 123-132. [CrossRef] [PubMed]

28. Kepp, O.; Senovilla, L.; Vitale, I.; Vacchelli, E.; Adjemian, S.; Agostinis, P.; Apetoh, L.; Aranda, F.; Barnaba, V.; Bloy, N.; et al. Consensus guidelines for the detection of immunogenic cell death. Oncoimmunology 2014, 3, e955691. [CrossRef]

29. Fucikova, J.; Kralikova, P.; Fialova, A.; Brtnicky, T.; Rob, L.; Bartunkova, J.; Spisek, R. Human tumor cells killed by anthracyclines induce a tumor-specific immune response. Cancer Res. 2011, 71, 4821-4833. [CrossRef] 
30. Tesniere, A.; Schlemmer, F.; Boige, V.; Kepp, O.; Martins, I.; Ghiringhelli, F.; Aymeric, L.; Michaud, M.; Apetoh, L.; Barault, L.; et al. Immunogenic death of colon cancer cells treated with oxaliplatin. Oncogene 2010, 29, 482-491. [CrossRef]

31. Tongu, M.; Harashima, N.; Yamada, T.; Harada, T.; Harada, M. Immunogenic chemotherapy with cyclophosphamide and doxorubicin against established murine carcinoma. Cancer Immunol. Immunother. 2010, 59, 769-777. [CrossRef] [PubMed]

32. Sukkurwala, A.Q.; Adjemian, S.; Senovilla, L.; Michaud, M.; Spaggiari, S.; Vacchelli, E.; Baracco, E.E.; Galluzzi, L.; Zitvogel, L.; Kepp, O.; et al. Screening of novel immunogenic cell death inducers within the NCI Mechanistic Diversity Set. Oncoimmunology 2014, 3, e28473. [CrossRef] [PubMed]

33. Obeid, M.; Tesniere, A.; Ghiringhelli, F.; Fimia, G.M.; Apetoh, L.; Perfettini, J.-L.; Castedo, M.; Mignot, G.; Panaretakis, T.; Casares, N.; et al. Calreticulin exposure dictates the immunogenicity of cancer cell death. Nat. Med. 2007, 13, 54-61. [CrossRef] [PubMed]

34. Pauwels, B.; Korst, A.E.C.; de Pooter, C.M.J.; Pattyn, G.G.O.; Lambrechts, H.A.J.; Baay, M.F.D.; Lardon, F.; Vermorken, J.B. Comparison of the sulforhodamine B assay and the clonogenic assay for in vitro chemoradiation studies. Cancer Chemother. Pharmacol. 2003, 51, 221-226. [CrossRef] [PubMed]

35. Van Loenhout, J.; Flieswasser, T.; Freire Boullosa, L.; De Waele, J.; Van Audenaerde, J.; Marcq, E.; Jacobs, J.; Lin, A.; Lion, E.; Dewitte, H.; et al. Cold Atmospheric Plasma-Treated PBS Eliminates Immunosuppressive Pancreatic Stellate Cells and Induces Immunogenic Cell Death of Pancreatic Cancer Cells. Cancers 2019, 11. [CrossRef] [PubMed]

36. Smits, E.L.J.M.; Ponsaerts, P.; Van de Velde, A.L.R.; Van Driessche, A.; Cools, N.; Lenjou, M.; Nijs, G.; Van Bockstaele, D.R.; Berneman, Z.N.; Van Tendeloo, V.F.I. Proinflammatory response of human leukemic cells to dsRNA transfection linked to activation of dendritic cells. Leukemia 2007, 21, 1691-1699. [CrossRef]

37. Vanmeerbeek, I.; Sprooten, J.; De Ruysscher, D.; Tejpar, S.; Vandenberghe, P.; Fucikova, J.; Spisek, R.; Zitvogel, L.; Kroemer, G.; Galluzzi, L.; et al. Trial watch: Chemotherapy-induced immunogenic cell death in immuno-oncology. Oncoimmunology 2020, 9, 1703449. [CrossRef]

38. Mehmood, R.K. Review of Cisplatin and oxaliplatin in current immunogenic and monoclonal antibody treatments. Oncol. Rev. 2014, 8, 256. [CrossRef]

39. Martins, I.; Kepp, O.; Schlemmer, F.; Adjemian, S.; Tailler, M.; Shen, S.; Michaud, M.; Menger, L.; Gdoura, A.; Tajeddine, N.; et al. Restoration of the immunogenicity of cisplatin-induced cancer cell death by endoplasmic reticulum stress. Oncogene 2011, 30, 1147-1158. [CrossRef]

40. Shi, S.; Tan, P.; Yan, B.; Gao, R.; Zhao, J.; Wang, J.; Guo, J.; Li, N.; Ma, Z. ER stress and autophagy are involved in the apoptosis induced by cisplatin in human lung cancer cells. Oncol. Rep. 2016, 35, 2606-2614. [CrossRef]

41. Mandic, A.; Hansson, J.; Linder, S.; Shoshan, M.C. Cisplatin induces endoplasmic reticulum stress and nucleus-independent apoptotic signaling. J. Biol. Chem. 2003, 278, 9100-9106. [CrossRef] [PubMed]

42. Xu, Y.; Wang, C.; Su, J.; Xie, Q.; Ma, L.; Zeng, L.; Yu, Y.; Liu, S.; Li, S.; Li, Z.; et al. Tolerance to endoplasmic reticulum stress mediates cisplatin resistance in human ovarian cancer cells by maintaining endoplasmic reticulum and mitochondrial homeostasis. Oncol. Rep. 2015, 34, 3051-3060. [CrossRef] [PubMed]

43. Raudenska, M.; Balvan, J.; Fojtu, M.; Gumulec, J.; Masarik, M. Unexpected therapeutic effects of cisplatin. Metallomics 2019, 11, 1182-1199. [CrossRef] [PubMed]

44. Sukkurwala, A.Q.; Martins, I.; Wang, Y.; Schlemmer, F.; Ruckenstuhl, C.; Durchschlag, M.; Michaud, M.; Senovilla, L.; Sistigu, A.; Ma, Y.; et al. Immunogenic calreticulin exposure occurs through a phylogenetically conserved stress pathway involving the chemokine CXCL8. Cell Death Differ. 2014, 21, 59-68. [CrossRef]

45. Anderson, I.C.; Mari, S.E.; Broderick, R.J.; Mari, B.P.; Shipp, M.A. The angiogenic factor interleukin 8 is induced in non-small cell lung cancer/pulmonary fibroblast cocultures. Cancer Res. 2000, 60, 269-272.

46. Zhu, Y.M.; Webster, S.J.; Flower, D.; Woll, P.J. Interleukin-8/CXCL8 is a growth factor for human lung cancer cells. Br. J. Cancer 2004, 91, 1970-1976. [CrossRef]

47. Rebe, C.; Demontoux, L.; Pilot, T.; Ghiringhelli, F. Platinum Derivatives Effects on Anticancer Immune Response. Biomolecules 2019, 10.

48. Di Blasio, S.; Wortel, I.M.N.; van Bladel, D.A.G.; de Vries, L.E.; Duiveman-de Boer, T.; Worah, K.; de Haas, N.; Buschow, S.I.; de Vries, I.J.M.; Figdor, C.G.; et al. Human CD1c(+) DCs are critical cellular mediators of immune responses induced by immunogenic cell death. Oncoimmunology 2016, 5, e1192739. [CrossRef] 
49. Golden, E.B.; Frances, D.; Pellicciotta, I.; Demaria, S.; Helen Barcellos-Hoff, M.; Formenti, S.C. Radiation fosters dose-dependent and chemotherapy-induced immunogenic cell death. Oncoimmunology 2014, 3, e28518. [CrossRef]

50. Schaer, D.A.; Geeganage, S.; Amaladas, N.; Lu, Z.H.; Rasmussen, E.R.; Sonyi, A.; Chin, D.; Capen, A.; Li, Y.; Meyer, C.M.; et al. The Folate Pathway Inhibitor Pemetrexed Pleiotropically Enhances Effects of Cancer Immunotherapy. Clin. Cancer Res. 2019, 25, 7175-7188. [CrossRef]

51. Schiavoni, G.; Sistigu, A.; Valentini, M.; Mattei, F.; Sestili, P.; Spadaro, F.; Sanchez, M.; Lorenzi, S.; D’Urso, M.T.; Belardelli, F.; et al. Cyclophosphamide synergizes with type I interferons through systemic dendritic cell reactivation and induction of immunogenic tumor apoptosis. Cancer Res. 2011, 71, 768-778. [CrossRef] [PubMed]

52. Du, B.; Waxman, D.J. Medium dose intermittent cyclophosphamide induces immunogenic cell death and cancer cell autonomous type I interferon production in glioma models. Cancer Lett. 2019, 470, 170-180. [CrossRef] [PubMed]

53. Gao, Q.; Wang, S.; Chen, X.; Cheng, S.; Zhang, Z.; Li, F.; Huang, L.; Yang, Y.; Zhou, B.; Yue, D.; et al. Cancer-cell-secreted CXCL11 promoted CD8(+) T cells infiltration through docetaxel-induced-release of HMGB1 in NSCLC. J. Immunother. Cancer 2019, 7, 42. [CrossRef] [PubMed]

54. Hodge, J.W.; Garnett, C.T.; Farsaci, B.; Palena, C.; Tsang, K.-Y.; Ferrone, S.; Gameiro, S.R. Chemotherapy-induced immunogenic modulation of tumor cells enhances killing by cytotoxic T lymphocytes and is distinct from immunogenic cell death. Int. J. Cancer 2013, 133, 624-636. [CrossRef] [PubMed]

55. Galluzzi, L.; Vitale, I.; Warren, S.; Adjemian, S.; Agostinis, P.; Martinez, A.B.; Chan, T.A.; Coukos, G.; Demaria, S.; Deutsch, E.; et al. Consensus guidelines for the definition, detection and interpretation of immunogenic cell death. J. Immunother. Cancer 2020, 8, e000337. [CrossRef]

56. Garg, A.D.; Vandenberk, L.; Koks, C.; Verschuere, T.; Boon, L.; Van Gool, S.W.; Agostinis, P. Dendritic cell vaccines based on immunogenic cell death elicit danger signals and $\mathrm{T}$ cell-driven rejection of high-grade glioma. Sci. Transl. Med. 2016, 8, 328ra27. [CrossRef]

57. Gandhi, L.; Rodriguez-Abreu, D.; Gadgeel, S.; Esteban, E.; Felip, E.; De Angelis, F.; Domine, M.; Clingan, P.; Hochmair, M.J.; Powell, S.F.; et al. Pembrolizumab plus Chemotherapy in Metastatic Non-Small-Cell Lung Cancer. N. Engl. J. Med. 2018, 378, 2078-2092. [CrossRef]

58. Paz-Ares, L.; Luft, A.; Vicente, D.; Tafreshi, A.; Gumus, M.; Mazieres, J.; Hermes, B.; Cay Senler, F.; Csoszi, T.; Fulop, A.; et al. Pembrolizumab plus Chemotherapy for Squamous Non-Small-Cell Lung Cancer. N. Engl. J. Med. 2018, 379, 2040-2051. [CrossRef] 